\title{
CAULIFLOWER GROWTH AND YIELD IN A HYDROPONIC SYSTEM WITH BRACKISH WATER ${ }^{1}$
}

\author{
LEANDRO FERREIRA DA COSTA ${ }^{2 *}$, TALES MILER SOARES ${ }^{2}$, MAIRTON GOMES DA SILVA $^{2}$, FRANCISCO \\ JOSÉ NUNES MODESTO ${ }^{2}$, LAILA DE ANDRADE QUEIROZ ${ }^{3}$, JULIANA DE SOUZA PEREIRA ${ }^{2}$
}

\begin{abstract}
The Brazilian semiarid is historically characterized by the water scarcity of good-quality. In this region there is great availability of groundwater reserves, however, these waters has high concentrations of dissolved salts, that makes them inappropriate to be used in the irrigation of most crops. The objective of this study was to evaluate the growth, production and salinity tolerance of three cauliflower cultivars in hydroponics NFT (Nutrient Film Technique), subjected to different electrical conductivities of the nutrient solution (ECsol) prepared with saline water. The experiment was carried out in a randomized blocks design in split-plot, with six replications. The plants were subjected to six levels of ECsol (1.94 - control, 3.24, 4.10, 5.04, 5.92 and $7.01 \mathrm{dS} \mathrm{m}^{-1}$ ) in the main plots, with three cauliflower cultivars ('Piracicaba de Verão', 'Sabrina' and 'SF1758') in the subplots, which were grown in the same hydroponic channel. Vegetative growth, inflorescence production and salinity tolerance of cultivars were evaluated. In general, except for the number of leaves, leaf width and fresh matters of leaves and shoot, the different ECsol levels negatively influenced the vegetative growth and inflorescences yield of cultivars cauliflower. The cultivars 'Piracicaba de Verão' and 'Sabrina' were considered moderately sensitive to salinity, while cultivar 'SF1758' was moderately tolerant to salinity.
\end{abstract}

Keywords: Brassica oleracea var. botrytis. Soilless cultivation. Semiarid. Salinity.

\section{CRESCIMENTO E PRODUÇÃO DA COUVE-FLOR EM HIDROPONIA COM ÁGUAS SALOBRAS}

RESUMO - O Semiárido brasileiro é historicamente caracterizado pela escassez de recursos hídricos de boa qualidade. Nessa região há uma grande disponibilidade de água de reservas subterrâneas, no entanto, apresentam elevadas concentrações de sais, que as tornam inapropriadas para irrigação da maioria das culturas. Objetivou-se com este estudo avaliar o crescimento, a produção e a tolerância à salinidade de três cultivares de couve-flor em hidroponia NFT (Nutrient Film Technique), submetidas a diferentes condutividades elétricas da solução nutritiva (CEsol) preparadas com águas salinizadas. O experimento foi conduzido em blocos casualizados em parcelas subdivididas, com seis repetições. As plantas foram submetidas a seis níveis de CEsol (1,94 - controle; 3,$24 ; 4,10 ; 5,04 ; 5,92$ e 7,01 dS m$\left.~^{-1}\right)$ nas parcelas principais, com três cultivares de couve-flor ('Piracicaba de Verão', 'Sabrina' e 'SF1758') nas subparcelas, quando foram cultivadas no mesmo canal hidropônico. Avaliaram-se o crescimento vegetativo, a produção de inflorescências e a tolerância à salinidade das cultivares. De maneira geral, com exceção do número de folhas, largura foliar e as massas de matéria fresca das folhas e da parte aérea, os diferentes níveis de CEsol influenciaram negativamente o crescimento vegetativo e o rendimento das inflorescências das cultivares da couve-flor. As cultivares 'Piracicaba de Verão' e 'Sabrina' foram consideradas moderadamente sensíveis à salinidade, enquanto a cultivar 'SF1758' foi moderadamente tolerante à salinidade.

Palavras-chave: Brassica oleracea var. botrytis. Cultivo sem solo. Semiárido. Salinidade.

\footnotetext{
${ }^{*}$ Corresponding author

${ }^{1}$ Received for publication in $01 / 27 / 2020$; accepted in $06 / 22 / 2020$.

Paper extracted from the masters dissection of the first author.

${ }^{2}$ Center of Agricultural, Environmental and Biological Sciences, Universidade Federal do Recôncavo da Bahia, Cruz das Almas, BA, Brazil; leandroifbaianobonfim@gmail.com - ORCID: 0000-0002-0321-8684, talesmiler@gmail.com - ORCID: 0000-0001-8157-7204, mairtong@hotmail.com - ORCID: 0000-0003-2140-201X, fjmodesto@gmail.com - ORCID: 0000-0002-0814-2594, julianasouzaa10@hotmail.com - ORCID: 0000-0001-7313-3750.

${ }^{3}$ Center of Exact and Technological Sciences, Universidade Federal do Recôncavo da Bahia, Cruz das Almas, BA, Brazil; lailadandrad@hotmail.com - ORCID: 0000-0001-7763-4202.
} 


\section{INTRODUCTION}

Large part of the Brazilian territory is under semiarid climate, which has limiting the regularity of agricultural and industrial productions, causing significant socioeconomic impacts. The low rainfall and hydrogeology of the Semiarid region of Brazil hinder the storage of groundwater, which are usually brackish and explored at low flow rates. This region has thousands of abandoned wells, or wells that are not intended to agricultural activities (SOARES et al., 2010).

The adoption of adequate technologies can mitigate the impacts caused by water scarcity. Thus, the hydroponic production system has been proposed as an alternative to conventional cultivation, providing greater efficiency in the use of water and lower risks associated with the use of brackish waters.

According to Tavakkoli, Rengasamy and McDonald (2010), plants that grow in soils with high salt contents have problems with the osmotic potential of the soil solution and soil matric potential, whereas the uptake of water for hydroponic crops considers only the osmotic potential of the solution.

This is one of the reasons crops grown in hydroponic systems tend to be more tolerant to salt stress and use water more efficiently for their development (SOARES et al., 2009; SOARES et al., 2010; FREITAS et al., 2019). Thus, several researches have been conducted using waters rich in salts for hydroponic production (WAN et al., 2010; AUGUSTO et al., 2012; BIONE et al., 2014).

Despite hydroponic systems offer high availability of potentially toxic ions to plants, a regular monitoring of electrical conductivity, $\mathrm{pH}$, nitrate content, and other parameters of the solution can assist in maintaining the nutrient balance, and even indicates the time the solution requires to be replaced (RODRIGUES, 2002).

Considering the high costs of hydroponic systems, crops with short cycles and higher profitability, such as vegetables, are usually recommended. The Brassicaceae family has several species of economic interest, but their tolerance to salt stress are usually little known. In Brazil it is typically cauliflower is one of these species that have high economic interest, which is grown in the autumn-winter season and has been expanded to hotter regions of the country due to breeding studies (MAY et al., 2007).

Some studies have evaluated cauliflower plants grown in soil (De PASCALE; MAGGIO; BARBIERI, 2005), pots with sand (GIUFFRIDA et al., 2013; GIUFFRIDA et al., 2017; GIUFFRIDA et al., 2018), and NFT (Nutrient Film Technique) hydroponic system (CRUZ et al., 2018; SOARES et al., 2020) under salt stress conditions. De Pascale, Maggio and Barbieri (2005) determined a threshold salinity of $1.52 \mathrm{dS} \mathrm{m}^{-1}$ for cauliflower in soil irrigated with brackish waters. These authors used the crop tolerance classification model proposed by Ayers and Westcot (1985), and classified the cauliflower as moderately sensitive to salt stress; although little quantitative data on its tolerance is available. In addition, data on cauliflower tolerance to saline stress for hydroponic systems are not found.

In this context, the objective of the present study was to evaluate the tolerance to salt stress of three cauliflower cultivars grown in a hydroponic system with brackish waters, regarding their vegetative growth and inflorescence production.

\section{MATERIAL AND METHODS}

The study was conducted with three cauliflower cultivars (Brassica oleracea var. botrytis) 'Piracicaba de Verão', 'Sabrina' and 'SF1758' under hydroponic conditions in a greenhouse (East-West orientation and uncontrolled environment), from April to July 2019 (autumnwinter). The greenhouse structure used was in a simple arch, with ceiling height of $4.0 \mathrm{~m}, 7.0 \mathrm{~m}$ wide and $32 \mathrm{~m}$ long, protected on the sides by black shade screen, and covered by $150 \mu \mathrm{m}$ thick polyethylene film. The study site is part of the experimental area of the Post-Graduate Program in Agricultural Engineering, at the Soil and Water Engineering Nucleus, belonging to the Federal University of Recôncavo of Bahia, in Cruz das Almas, Bahia, Brazil (12 40' 19' S, 39 06' 23' W, and at an elevation of $220 \mathrm{~m}$ above sea level).

The local climate is classified as Af type (hot and humid tropical) according to the classification by Köppen (ALVARES et al., 2013), with annual means of precipitation, air temperature and relative humidity of $1,224 \mathrm{~mm}, 24.5{ }^{\circ} \mathrm{C}$ and $80 \%$, respectively. During the experiment, outside the greenhouse, the minimum, maximum and mean air temperature values were $20.90,28.20$ and $23.80{ }^{\circ} \mathrm{C}$ and relative humidity of $85.01,90.42$ and $87.85 \%$, respectively (INMET, 2019).

The experiment was carried out in a randomized blocks design in split-plot, with six replications. The plants were subjected to six levels of electrical conductivities of the nutrient solution (ECsol): 1.94 (control, without $\mathrm{NaCl}$ ), 3.24, 4.10, 5.04, 5.92 and $7.01 \mathrm{dS} \mathrm{m}^{-1}$ in the main plots, with three cauliflower cultivars ('Piracicaba de Verão', 'Sabrina' and 'SF1758') in the subplots, which were grown in the same hydroponic channel (plots). In the total, 108 subplots were used (each one containing three plants).

By the end of the experiment, the ECsol values evaluated every 2 days were used to obtain the mean time-weighted ECsol (1.4, 2.6, 3.5, 4.6,

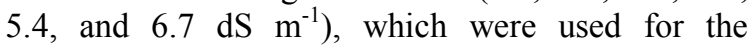
statistical analysis of the obtained data. 
The cauliflower plants were grown in a NFT (Nutrient Film Technique) hydroponic system, in hydroponic channels (PVC pipes of $0.075 \mathrm{~m}$ in diameter) with $6 \mathrm{~m}$ long. The channels were installed with a $3 \%$ slope, thus allowing the nutrient solution to drain into the storage reservoir by gravity, after each circulation event. Two hydroponic channels were used per bench, spaced $0.80 \mathrm{~m}$ apart, with a $0.56 \mathrm{~m}$ spacing between plants.

Each plot had a plastic tank (60 L capacity) to store the nutrient solution, equipped with a float valve that allowed maintaining a constant volume of solution $(50 \mathrm{~L})$ and an electric pump to inject the solution into the channel. There was also an individualized water supply tank for each plot, responsible for replenishment of water consumed by plants. This supply tank was built with a 0.20 -mdiameter PVC tube, with capacity for $20 \mathrm{~L}$, with graduated scale fixed outside next to a transparent tube installed in the vertical position to allow the reading of the water level in the tank.

The three cauliflower cultivars ('Piracicaba de Verão', 'Sabrina' and 'SF1758'), which have white inflorescences color, were selected according to their commercial availability and tolerance to heat. For each cultivar, were sown two seed per phenolic foam cell $(0.02 \times 0.02 \times 0.02 \mathrm{~m})$. Irrigations were conducted daily with public-supply water (electrical conductivity - ECW of $0.3 \mathrm{dS} \mathrm{m}^{-1}$ ) during the first five days. After this period, the thinning was carried out, leaving one seedling per cell, and were transferred to a nursery (NFT system), where they received nutrient solution of Furlani et al. (1999) for leafy vegetables at $50 \%$ concentration for 23 days.

The seedlings of cauliflower were transplanted to the hydroponic channels at 28 days after sowing (four leaf stage and selected by uniform size), when the treatments started. Each hydroponic channel had three seedlings of each cultivar.

In the final cultivation system, the nutrient solutions were prepared in artificially salinated waters by addition of $\mathrm{NaCl}$ to public-supply water ( $\mathrm{ECW} 0.3 \mathrm{dS} \mathrm{m} \mathrm{m}^{-1}$ ), using the following salt concentrations: $0.714,1.377,1.888,2.399$ and 3.153 $\mathrm{g} \mathrm{L}^{-1}$. After that, fertilizer salts were added to these waters, using the nutrient solution recommended by Furlani et al. (1999) at 100\% concentration.

ECsol and $\mathrm{pH}$ were monitored during the experiment using a conductivity meter model DM-3P (Digimed Analítica Ltda., Brazil) and $\mathrm{pH}$ meter model HI-3220 (Hanna Instruments Brazil Exp. e Imp. Ltda.), respectively, with automatic temperature compensation. The cauliflower alkalized the nutrient solution over the experiment, requiring corrections of $\mathrm{pH}$ by applying sulfuric acid at $20 \%$, which was the concentration that better assisted in the control of
$\mathrm{pH}$ in the cauliflower crop, keeping the $\mathrm{pH}$ range between 5.5 and 6.5. The nutrient solution was managed by proportionally refilling the nutrients consumed by the plants when observing a decrease of $50 \%$ (approximately $1.0 \mathrm{dS} \mathrm{m}^{-1}$ ) in the ECsol of the control treatment (without $\mathrm{NaCl}$ ); similar criterion was adopted by Lira et al. (2015). The nutrient solution of all treatments was exchanged at 43 days after the transplanting (DAT).

In all treatments, the public-supply water (with constant $\mathrm{ECW}$ of $0.3 \mathrm{dS} \mathrm{m} \mathrm{m}^{-1}$ ) was used to replace the water consumption by the cauliflower plants.

The cauliflower inflorescences were harvested as they reached the point of harvest; the harvest period was 17 days (June 19 to July 05, 2019). The criterion for harvest was to consider the inflorescence compacity and firmness according to May et al. (2007).

In each main plot (hydroponic channel), one plant of each cultivar at the central position of each subplot was collected as the inflorescences were harvested. Stem diameter (SD), plant height (PH), number of leaves (NL), leaf length (LL), leaf width (LW), leaf area (LA), leaves fresh matter (LFM) and shoot fresh matter (SFM) were measured. SD was measured using a digital caliper. PH, LL and LW were measured using a tape. LA was measured using a portable leaf area meter model CI-202 (CID BioScience, Inc., Washington, USA). Immediately after weighing the fresh plants, the material was placed in paper bags and dried in a forced-air oven at temperature of $65{ }^{\circ} \mathrm{C}$ until constant weight, to quantify leaves dry matter (LDM) and shoot dry matter (SDM).

The number of days necessary for the cauliflower to reach the point of harvest was evaluated from the transplanting for the hydroponic channels, which was the period in which the plants were subjected to salt stress treatments until their harvest.

The harvested inflorescences were used to determine the inflorescence diameter (ID) and inflorescence height (IH), using a tape ruler. The inflorescence fresh matter yield (IFMY) was also determined.

The inflorescence diameters were classified according to Program Horti \& Fruti (PROGRAMA HORTI \& FRUTI, 2019) into eight classes: Class 1 (ID $<0.10 \mathrm{~m})$, Class $2(0.10 \leq$ ID $<0.13 \mathrm{~m})$, Class 3 $(0.13 \leq$ ID $<0.15 \mathrm{~m})$, Class $4(0.15 \leq$ ID $<0.17 \mathrm{~m})$, Class $5(0.17 \leq \mathrm{ID}<0.19 \mathrm{~m})$, Class $6(0.19 \leq \mathrm{ID}<$ $0.21 \mathrm{~m})$, Class $7(0.21 \leq \mathrm{ID}<0.23 \mathrm{~m})$, and Class 8 (ID $\geq 0.23 \mathrm{~m}$ ). According to this Program, the cauliflower classification by size has the objective of fairness in the marketing, best prices for producers, 
and better quality for consumers.

The cauliflower tolerance to salt stress was evaluated individually for each cultivar, based on the relative inflorescence fresh matter yield, using the plateau model with linear decrease proposed by Maas and Hoffman (1977). The parameters of the model were adjusted by minimizing the square of errors with the Solver tool of the Microsoft Excel, as done by Modesto et al. (2019).

The data were subjected to analysis of variance by $F$ test at 0.05 probability level. The means obtained as a function of the cauliflower cultivars were compared by the Tukey-test at 0.05 probability level, whereas the ECsol levels were evaluated by regression analysis. The variables were fitted to the linear model $(y=a x+b)$ by calculating the relative decrease per unit of ECsol increased, using the relation: $(a / b) \times 100$; where: ' $a$ ' is angular coefficient and ' $b$ ' linear coefficient. All variables were evaluated considering the time-weighted ECsol to work with more similar data to the actual salinization condition in the root zone. All statistical analyses were performed using SISVAR software, version 4.6 (FERREIRA, 2011).

\section{RESULTS AND DISCUSSION}

There was no significant interaction $(p>$ 0.05 ) in any vegetative growth variable, showing that the effect of saline stress was similar in the three cauliflower cultivars (Table 1). The different levels of electrical conductivity of the nutrient solution (ECsol) promoted significant differences $(\mathrm{p}<0.01)$ on plant height $(\mathrm{PH})$, stem diameter (SD), leaf length (LL), leaf area (LA) and shoot dry matter (SDM) of cauliflower plants. All vegetative growth variables were significantly influenced $(p<0.01)$ by the cauliflower cultivars.

The cultivars were compared and the variables showed, in general, higher means for the cultivar 'Piracicaba de Verão', except for SD and number of leaves (NL), with the cultivar 'SF1758' presenting the highest means. The lowest means were found, in general, for the cultivar 'Sabrina', with PH, LL, leaf width (LW), and leaves dry matter (LDM) means showing no significant differences to those obtained for cultivar 'SF1758' (Table 1).

Table 1. Summary of the F-test of the analysis of variance and mean values for plant height (PH), stem diameter (SD), number of leaves (NL), leaf length (LL), leaf width (LW), leaf area (LA), fresh matter of shoot (SFM) and leaves (LFM) and dry matter of shoot (SDM) and leaves (LDM) of three cauliflower cultivars grown under different electrical conductivities of the nutrient solution (ECsol) in a NFT hydroponic system.

\begin{tabular}{|c|c|c|c|c|c|c|c|c|c|c|}
\hline SV & $\mathrm{PH}$ & SD & NL & LL & LW & LA & SFM & LFM & SDM & LDM \\
\hline Blocks & ns & ns & ns & ns & ns & ns & ns & ns & ns & ns \\
\hline ECsol & $* *$ & $* *$ & ns & $* *$ & ns & $* *$ & ns & ns & $* *$ & ns \\
\hline Error1 & -- & -- & -- & -- & -- & -- & -- & -- & -- & -- \\
\hline $\mathrm{Cul}$ & $* *$ & $* *$ & $* *$ & $* *$ & $* *$ & $* *$ & $* *$ & $* *$ & $* *$ & $* *$ \\
\hline CulxECsol & ns & ns & ns & ns & ns & ns & ns & ns & ns & ns \\
\hline Error2 & -- & -- & -- & -- & -- & -- & -- & -- & -- & -- \\
\hline CV1 (\%) & 16.80 & 16.64 & 13.99 & 24.31 & 21.04 & 37.16 & 51.23 & 51.70 & 27.72 & 53.11 \\
\hline CV2 (\%) & 14.24 & 16.38 & 9.55 & 26.00 & 22.65 & 36.26 & 48.75 & 49.31 & 28.70 & 48.60 \\
\hline $\mathrm{Cul}$ & \multicolumn{10}{|c|}{ Means } \\
\hline $\begin{array}{l}\text { 'Piracicaba } \\
\text { de Verão' }\end{array}$ & $56.9 \mathrm{a}$ & $16.3 \mathrm{a}$ & $27.6 \mathrm{a}$ & $43.5 \mathrm{a}$ & $25.6 \mathrm{a}$ & $1042.0 \mathrm{a}$ & $1211.4 \mathrm{a}$ & $1063.7 \mathrm{a}$ & $63.7 \mathrm{a}$ & $61.9 \mathrm{a}$ \\
\hline 'Sabrina' & $46.3 b$ & $14.5 b$ & $25.3 b$ & $31.5 \mathrm{~b}$ & $18.8 \mathrm{~b}$ & $437.3 \mathrm{c}$ & $628.6 \mathrm{c}$ & $563.7 \mathrm{c}$ & $37.5 \mathrm{c}$ & $32.6 \mathrm{~b}$ \\
\hline 'SF1758' & $46.9 \mathrm{~b}$ & $16.0 \mathrm{a}$ & $28.1 \mathrm{a}$ & $29.6 \mathrm{~b}$ & $20.2 b$ & $583.5 \mathrm{~b}$ & $927.6 \mathrm{~b}$ & $818.9 \mathrm{~b}$ & $49.4 b$ & $41.7 \mathrm{~b}$ \\
\hline
\end{tabular}

$\mathrm{SV}$ - source of variation; Cul - cultivars; ** significant at $\mathrm{p}<0.01$ and ns - not significant by F-test; CV1 and CV2 coefficients of variation of the errors 1 and 2, respectively; means followed by the same letter in the column do not differ statistically by Tukey-test at $5 \%$ probability level.

According to the linear regression models, the variables $\mathrm{PH}$ (Figure 1A) and SD (Figure 1B) decreased with the same magnitude, 3.48 and $3.57 \%$, respectively, per unit of ECsol increased. The means related to the cauliflower leaf showed higher decreases; the LA had the highest decrease, with
$6.58 \%$ (Figure 1C), and the leaf length decreased $4.33 \%$ (Figure 1D) per unit of ECsol increased. Decreases with the same magnitude of that found for LA was found for the SDM (Figure 1E), with $6.14 \%$ per unit of ECsol increased. 


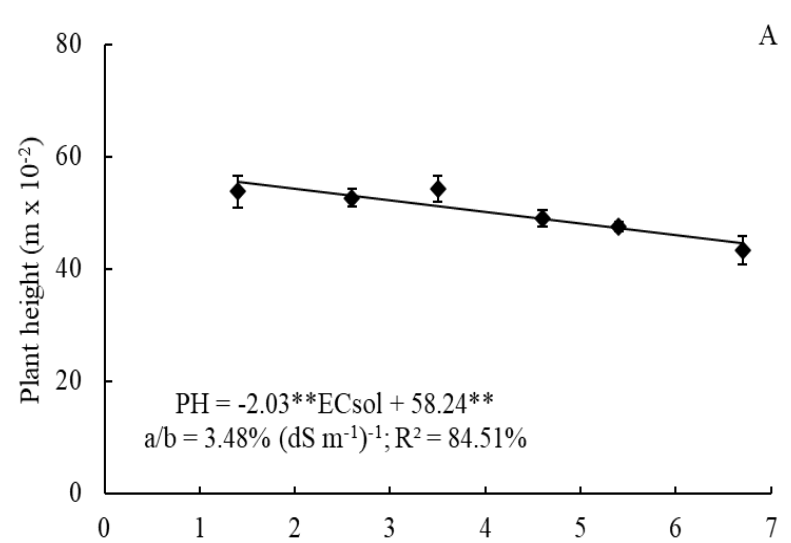

$$
\text { A }
$$
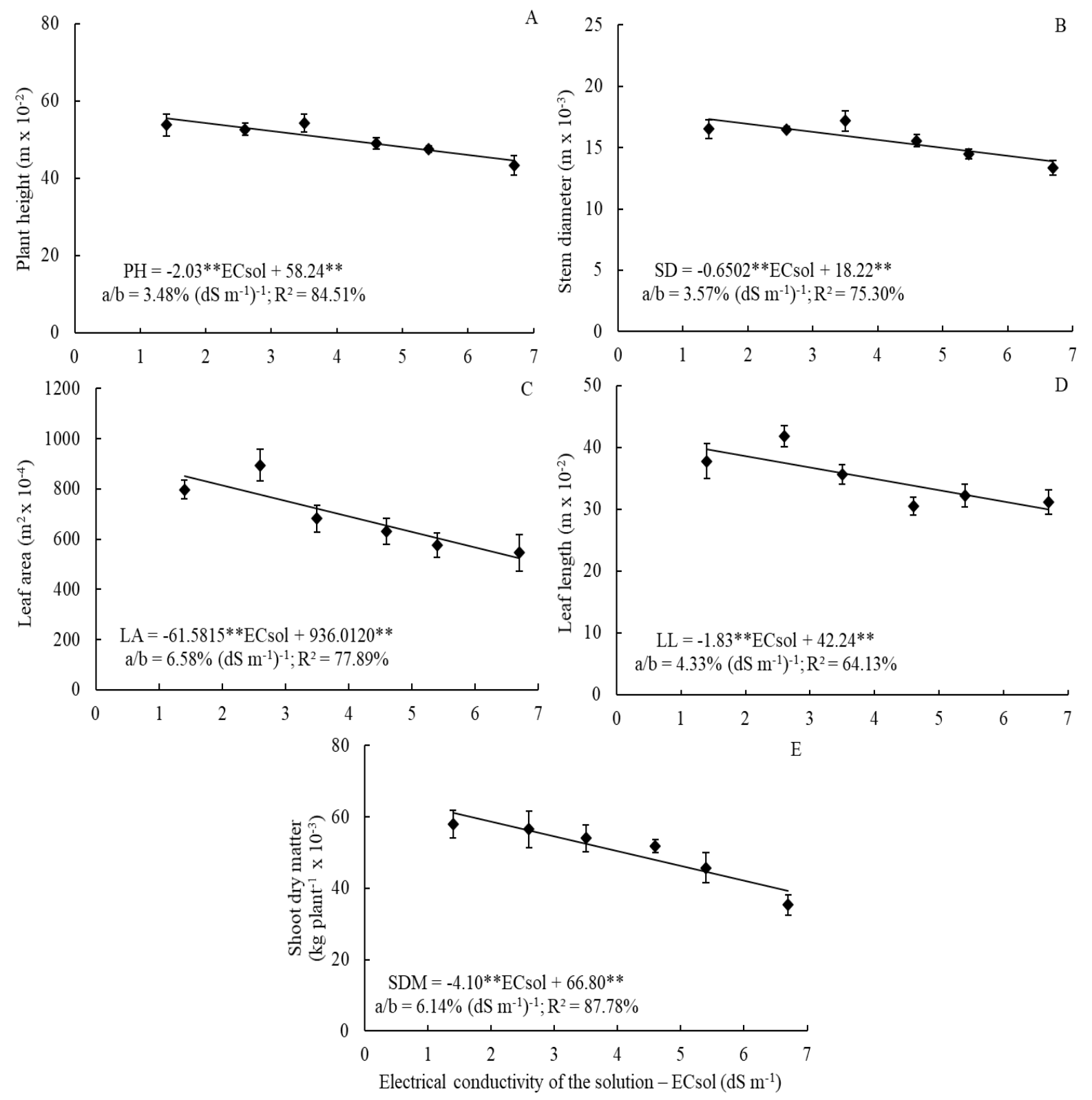

** - significant at $1 \%$ probability level by $\mathrm{t}$-test; the means are shown with the respective standard deviation $(\mathrm{n}=6)$.

Figure 1. Plant height - PH (A), stem diameter - SD (B), leaf area (C), leaf length - LL (D) and shoot dry matter - SDM (E) of cauliflower as a function of mean time-weighted of electrical conductivity of the nutrient solution (ECsol) in a NFT hydroponic system.

Studies found in the literature also have reported negative effects of salt stress on height and stem diameter of plants due to the use of brackish waters in the preparation of nutrient solutions for melon (DIAS et al., 2010), sunflower (NOBRE et al., 2010), tomato (GOMES et al., 2011), and basil (BIONE et al. 2014). Decreases in plant growth can be related to accumulation of $\mathrm{Na}^{+}$and $\mathrm{Cl}^{-}$ions in different plant tissues (JOUYBAN, 2012; ABDELGAWAD et al., 2016). Giuffrida et al. (2017) reported accumulation of these ions in different organs of cauliflower plants (leaves, stem, and roots) grown on nutrient solutions with electrical conductivities of 2 and $4 \mathrm{dS} \mathrm{m}^{-1}$.
The emission of new leaves was less sensitive to the salt stress than the LA. However, the number of leaves of a plant can affect the mechanism of tolerance to salt stress, because it is associated with total leaf area and can compensate losses caused by decreases in LA. It is direct related to the physical capacity of plants to compartmentalize $\mathrm{Na}^{+}$and $\mathrm{Cl}^{-}$ ions in the cell vacuole (MUNNS; TESTER, 2008). De Pascale, Maggio and Barbieri (2005) also reported that the number of leaves in cauliflower plants (cultivar 'Snow Prince') grown in soil does not decrease because of the salinity of the irrigation water (1.81 to $6.22 \mathrm{dS} \mathrm{m}^{-1}$ ).

Several studies also showed that the LA of 
cabbage (SANOUBAR et al., 2016) and rocket (SCHIATTONE et al., 2017) is sensitive to salt stress, which also are species of Brassicaceae family. Sanoubar et al. (2016) reported similar decreases to those found for in the present work, with relative decrease of $62 \%$ in LA of cabbage plants grown in a hydroponic system with high ECsol $\left(8.72 \mathrm{dS} \mathrm{m}^{-1}\right)$ when compared to the control (ECsol $2.68 \mathrm{dS} \mathrm{m}^{-1}$ ).

Despite the negative effect of the ECsol, the relative decrease in LA was $31.5 \%$ under the highest salinity $\left(6.7 \mathrm{dS} \mathrm{m}^{-1}\right)$ when compared to the control $\left(1.4 \mathrm{dS} \mathrm{m}^{-1}\right)$. These results were due to decreases in plants' capacity of uptake water under salt stress, which decrease the cell division rate and, consequently, the expansion of leaves, followed by stomatal closure and decreases in photosynthesis (RAHNAMA et al., 2010).

The LL decreased linearly as the ECsol was increased (Figure 1D). The LW was not affected by the ECsol (Table 1); thus, the leaf area was more affected by the leaf length. Leaf dimensions are important variables related to leaf area; Marcolini, Cecílio Filho and Barbosa (2005) reported that leaf area can be estimated through linear measures of leaf length and width.

SDM was also sensitive to salt stress, with decrease of $6.14 \%$ per unit of ECsol increased (Figure 1E). SDM corresponds to the weight of stem and leaves, thus, decreases in SD affect the SDM. According to Maggio et al. (2005), the percentage of dry matter of plants under salt stress is directly correlated to sensitivity of LA to salt stress, and the shoot weight decreases as the LA decreases.

Contrastingly, a similar work with cauliflower and broccoli plants found that salt stress (ECsol 2 and $4 \mathrm{dS} \mathrm{m}^{-1}$ ) is not the cause of decreases in dry weights of leaves and shoot of plants grown in pots using sand as substrate (GIUFFRIDA et al., 2013).

As observed for vegetative growth variables (Table 1), there was no significant interaction ( $p>$ $0.05)$ in any variable of the cauliflower inflorescences (Table 2). The ECsol levels promoted significant differences in inflorescence diameter - ID $(p<0.01)$ and inflorescence fresh matter yield IFMY $(\mathrm{p}<0.05)$, while the cauliflower cultivars significantly influenced $(p<0.01)$ the four inflorescence variables (ID, inflorescence height IH, IFMY and time to harvest the inflorescence THI).

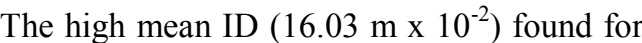
the cultivar 'Piracicaba de Verão' did not result in a higher mean inflorescence fresh matter, which was $358.01 \mathrm{~kg} \mathrm{x} 10^{-3}$ and statistically equal to the mean found for the cultivar 'Sabrina' (347.85 kg x 10 $\left.0^{-3}\right)$, which presented significantly lower ID than the cultivar 'Piracicaba de Verão'. Contrastingly, the IFMY of the cultivar 'SF1758' (425.56 kg x 10-3) was higher than that of the cultivar 'Piracicaba de Verão' and statistically equal to that found for the cultivar 'Sabrina' (Table 2). This indicates that the ID is not affected by IFMY and that the cultivar 'Piracicaba de Verão' has fewer compact heads, however, it is generally expected that higher ID in more compact heads will result in higher IFMY yields. The Figure 2 shows a little of the general appearance of the inflorescences of the three cultivars of cauliflower when submitted to different salinities in the NFT hydroponics.

The ID decreased only $1.92 \%$ per unit of ECsol increased (Figure 3A), percentage lower than that found for the SDM (6.14\%) (Figure 1E) and IFMY (4.64\%) (Figure 3B).

Table 2. Summary of the F-test of the analysis of variance and mean values for inflorescence diameter (ID), inflorescence height (IH), inflorescence fresh matter yield (IFMY) and time to harvest the inflorescence (THI) of three cauliflower cultivars grown under different electrical conductivities of the nutrient solution (ECsol) in a NFT hydroponic system.

\begin{tabular}{ccccc}
\hline Source of variation & ID & IH & IFMY & THI \\
\hline Blocks & ns & ns & ns & ns \\
ECsol & $* *$ & ns & $*$ & -- \\
Error1 & -- & -- & -- & $* *$ \\
Cultivar & $* *$ & $* *$ & $* *$ & ns \\
CultivarxECsol & ns & ns & -- & - \\
Error2 & -- & -- & 28.61 & 8.86 \\
CV1 (\%) & 5.55 & 9.46 & 25.12 & 6.09 \\
CV2 (\%) & 5.60 & 9.38 & $358.0 \mathrm{~b}$ & $61.3 \mathrm{a}$ \\
\hline 'Piracicaba de Verão' & $16.0 \mathrm{a}$ & $11.2 \mathrm{ab}$ & $347.8 \mathrm{~b}$ & $54.2 \mathrm{~b}$ \\
'Sabrina' & $14.7 \mathrm{~b}$ & $10.7 \mathrm{~b}$ & $425.6 \mathrm{a}$ & $61.6 \mathrm{a}$ \\
\hline
\end{tabular}

* and ** significant respectively at $\mathrm{p}<0.05$ and $\mathrm{p}<0.01$ and $\mathrm{ns}$ - not significant by F-test; CV1 and CV2 - coefficients of variation of the errors 1 and 2, respectively; means followed by the same letter in the column do not differ statistically by Tukey-test at $5 \%$ probability level. 
cv. 'SF1758'
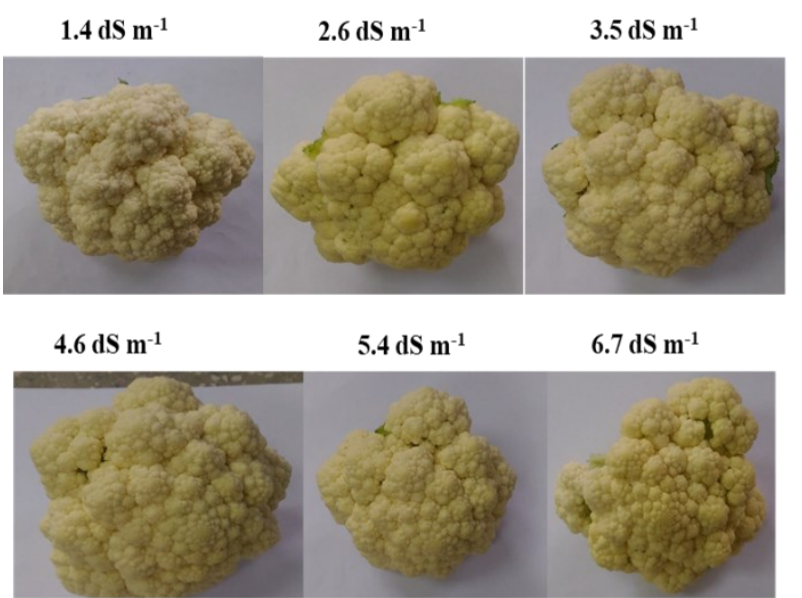

cv. 'Piracicaba de Verão'

cv. 'Sabrina'

$1.4 \mathrm{dS} \mathrm{m}^{-1} \quad 2.6 \mathrm{dS} \mathrm{m}^{-1}$

$3.5 \mathrm{dS} \mathrm{m}^{-1}$
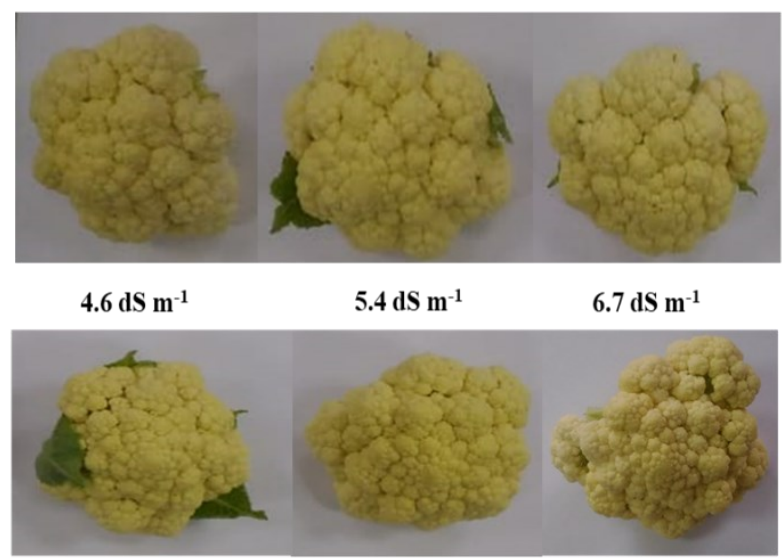

$4.6 \mathrm{dS} \mathrm{m}^{-1}$

$6.7 \mathrm{dS} \mathrm{m}^{-1}$

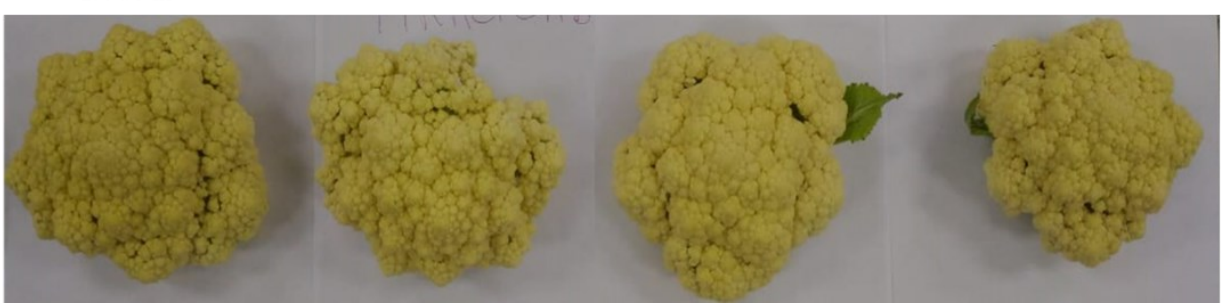

Figure 2. General aspect of the inflorescences of the three cauliflower cultivars in relation to the levels of electrical conductivity of the nutrient solution (ECsol) in a NFT hydroponic system.
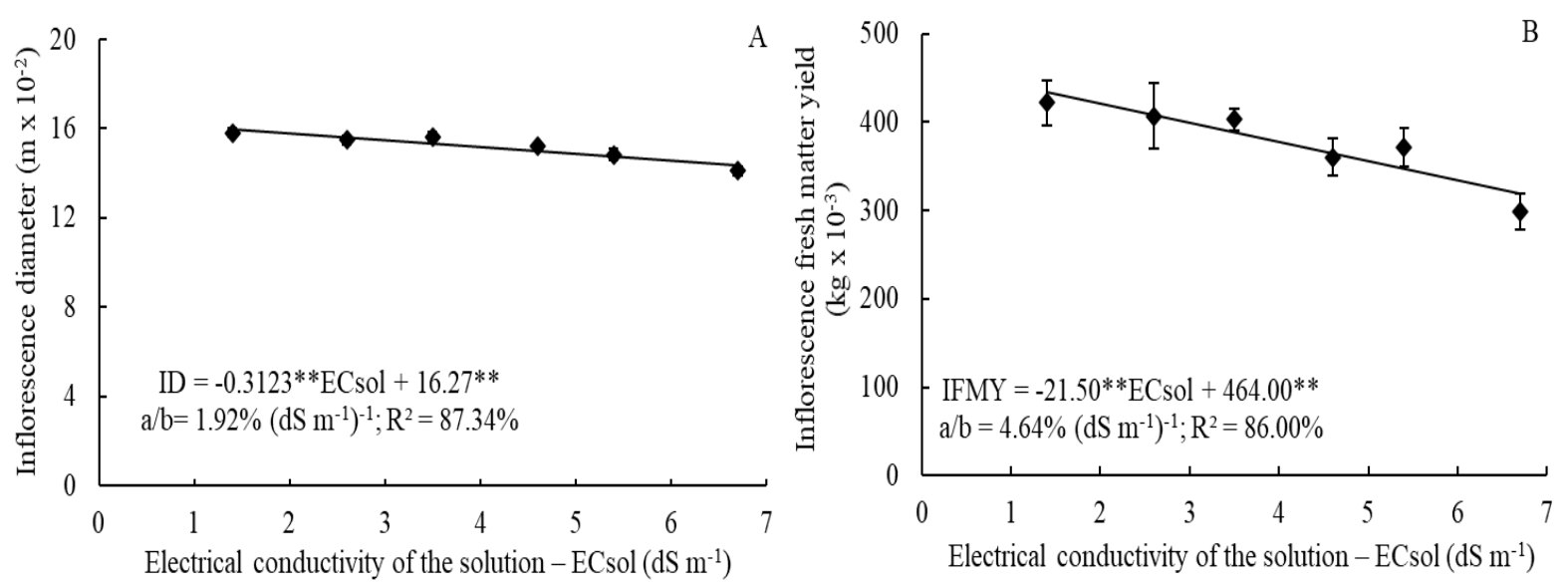

** - significant at $1 \%$ probability level by t-test; the means are shown with the respective standard deviation $(\mathrm{n}=6)$.

Figure 3. Inflorescence diameter - ID (A) and inflorescence fresh matter yield - IFMY (B) of cauliflower as a function of mean time-weighted of electrical conductivity of the nutrient solution (ECsol) in a NFT hydroponic system.

According to Programa Horti \& Fruti (2019) (Table 3), the ID of the cultivar 'Piracicaba de Verão' was classified as Class 4 , whereas the ID of the cultivars 'Sabrina' and 'SF1758' was classified as Class 3. According to Figure 3A, the mathematical model showed that the ID of plants grown under ECsol of $1.4 \mathrm{dS} \mathrm{m}-1$ tended to be classified as Class 4, with mean of $0.16 \mathrm{~m}$; and the other ECsol resulted in classifications in Class 3 (between 0.13 and $0.15 \mathrm{~m}$ ).

The highest ID values found were related, in general, to the highest inflorescence weights (when met the criteria of firmness and compacity), thus, the higher the class, the heavier the inflorescence. It implies a better price for the product, because cauliflower is marketed by weight. 
Table 3. Classification of diameters of cauliflower inflorescence (ID) according to Programa Horti \& Fruti (2019) as a function of mean time-weighted of electrical conductivity of the nutrient solution (ECsol) in a NFT hydroponic system.

\begin{tabular}{cccc}
\hline ECsol $\left(\mathrm{dS} \mathrm{m}^{-1}\right)$ & Observed ID $(\mathrm{m})$ & Reference ID $(\mathrm{m})$ & ID Class \\
1.4 & 0.16 & $>0.15 \mathrm{a} 0.17$ & 4 \\
2.6 & 0.15 & $>0.13 \mathrm{a} 0.15$ & 3 \\
3.5 & 0.15 & $>0.13 \mathrm{a} 0.15$ & 3 \\
4.6 & 0.15 & $>0.13 \mathrm{a} 0.15$ & 3 \\
5.4 & 0.15 & $>0.13$ a 0.15 & 3 \\
6.7 & 0.15 & $>0.13$ a 0.15 & 3 \\
\hline
\end{tabular}

Despite the salt stress caused no toxicity and deformity on the cauliflower inflorescences, the ID decreased. This decrease is consistent with the findings of Giuffrida et al. (2013) for cauliflower plants grown in pots irrigated with water containing $\mathrm{NaCl}$ concentrations of 0,2 , and $4 \mathrm{dS} \mathrm{m} \mathrm{m}^{-1}$; they found a relative decrease of $14.8 \%$ when comparing the control to the highest salinity $\left(4 \mathrm{dS} \mathrm{m} \mathrm{m}^{-1}\right)$. The relative decrease found in the present study was $10.75 \%$ when comparing the control $\left(1.4 \mathrm{dS} \mathrm{m}^{-1}\right)$ to the highest salinity $\left(6.7 \mathrm{dS} \mathrm{m}^{-1}\right)$. In a similar work with cauliflower plants, Giuffrida et al. (2018) did not attributed the decreases in ID to the salinity of the nutrient solution; however, the inflorescence height had a relative decreased of $22.7 \%$ when comparing the highest salinity level $\left(4 \mathrm{dS} \mathrm{m}^{-1}\right)$ to the control $\left(2 \mathrm{dS} \mathrm{m}^{-1}\right)$. Contrastingly, the present study showed that the salt stress did not decrease the inflorescence height.

The ECsol did not affect the time the cauliflower required to reach the harvest point; therefore, the difference found was only due to the cultivars used. Decreases in crop cycle caused by brackish waters in hydroponic systems can be a response to the salt effects on the plants, since the lower the exposure time, the lower the absorption and accumulation of ions in plants (SOARES et al., 2010). However, the results obtained showed no occurrence of this effect.

Considering the salt stress conditions in the present study, the IFMY decreased as the ECsol was increased. This result was also found by Giuffrida et al. (2017) for cauliflower plants grown in pots with sand and subjected to two ECsol $\left(2\right.$ and $\left.4 \mathrm{dS} \mathrm{m}^{-1}\right)$, presenting a relative decrease of $25 \%$ in the IFMY when using the highest salinity level.

Decreases in crop yield due to the use of brackish waters are explained by decreases in osmotic potential in the root area, which decrease water absorption and, consequently, decrease the water potential in the plant and the processes of cell division and expansion (NEUMANN, 1997; MUNNS, 2002). Ding et al. (2018) evaluated species of the Brassicaceae family and found that the use of high ECsol inhibits plant growth, negatively affecting the production of plants, since the plants need to adjust their metabolism to attenuate the salt stress.

Regarding the cauliflower tolerance to salt stress, the Maas and Hoffman (1977) model used for the three cauliflower cultivars evaluated was chosen because the relative yield of the cultivars were higher than $50 \%$, which is a criterion established for use of this model. This model determines the electrical conductivity threshold for nutrient solutions, which is an importance parameter to understand the tolerance of hydroponic crops to salt stress. De Pascale, Maggio and Barbieri (2005) used the Maas and Hoffman (1977) model and estimated a threshold of $1.52 \mathrm{dS} \mathrm{m}^{-1}$ for cauliflower plants grown in soil irrigated with brackish waters; they found a decrease in relative yield of $14.4 \%$ per unit of ECsol increased above the estimated threshold.

The cauliflower inflorescence relative production data enabled to determine the tolerance of each cultivar evaluated (Figure 4). The fitting of the parameters to the model of tolerance to salt stress proposed by Maas and Hoffman (1977) determined the respective salinity thresholds: $2.60 \mathrm{dS} \mathrm{m}^{-1}$ for the cultivar 'Piracicaba de Verão' (Figure 4A), 2.65 dS $\mathrm{m}^{-1}$ for the cultivar 'Sabrina' (Figure 4B), and 3.20 $\mathrm{dS} \mathrm{m} \mathrm{m}^{-1}$ for the cultivar 'SF1758' (Figure 4C). Despite the cultivar 'SF1758' showing the highest salinity threshold $\left(3.20 \mathrm{dS} \mathrm{m}^{-1}\right)$, this cultivar has a percentage $9.6 \%$ reduction in fresh matter from the inflorescence per unitary increase ECsol beyond its threshold. In contrast, the cultivars 'Piracicaba de Verão' and 'Sabrina' showed salinity thresholds of $2.60 \mathrm{dS} \mathrm{m} \mathrm{m}^{-1}$ and $2.65 \mathrm{dS} \mathrm{m}^{-1}$ with percentage reductions of $7.3 \%$ and $6.9 \%$ by unit addition of ECsol above the threshold, respectively.

Based on the estimated salinity thresholds for the cauliflower cultivars in hydroponic systems, the cultivars 'Sabrina' and 'Piracicaba de Verão' are classified as moderately sensitive $\left(1.3-3.0 \mathrm{dS} \mathrm{m}^{-1}\right)$, and the cultivar 'SF 1758' as moderately tolerant (3.0 - $\left.6.0 \mathrm{dS} \mathrm{m}^{-1}\right)$, according to the salinity ranges proposed by Ayers and Westcot (1985). However, this classification was developed for crops grown in soil, and the comparison between the salinity of the saturated soil extract and the salinity of the nutrient solution in hydroponics is difficult.

Nevertheless, plants grown in hydroponic systems may show higher tolerance to salt stress and 
present higher salinity threshold than that found for those grown in soil. For example, the salinity threshold of $1.52 \mathrm{dS} \mathrm{m}^{-1}$ found by De Pascale, Maggio and Barbieri (2005) for plants grown in soil probably would be higher in hydroponic systems. Similarly, the thresholds found for the three cultivars tested in the present study could be lower if the tested plants were grown in soil. Therefore, the salinity threshold of a crop may be relative and present different results when comparing different production systems or cultivars of the same species.

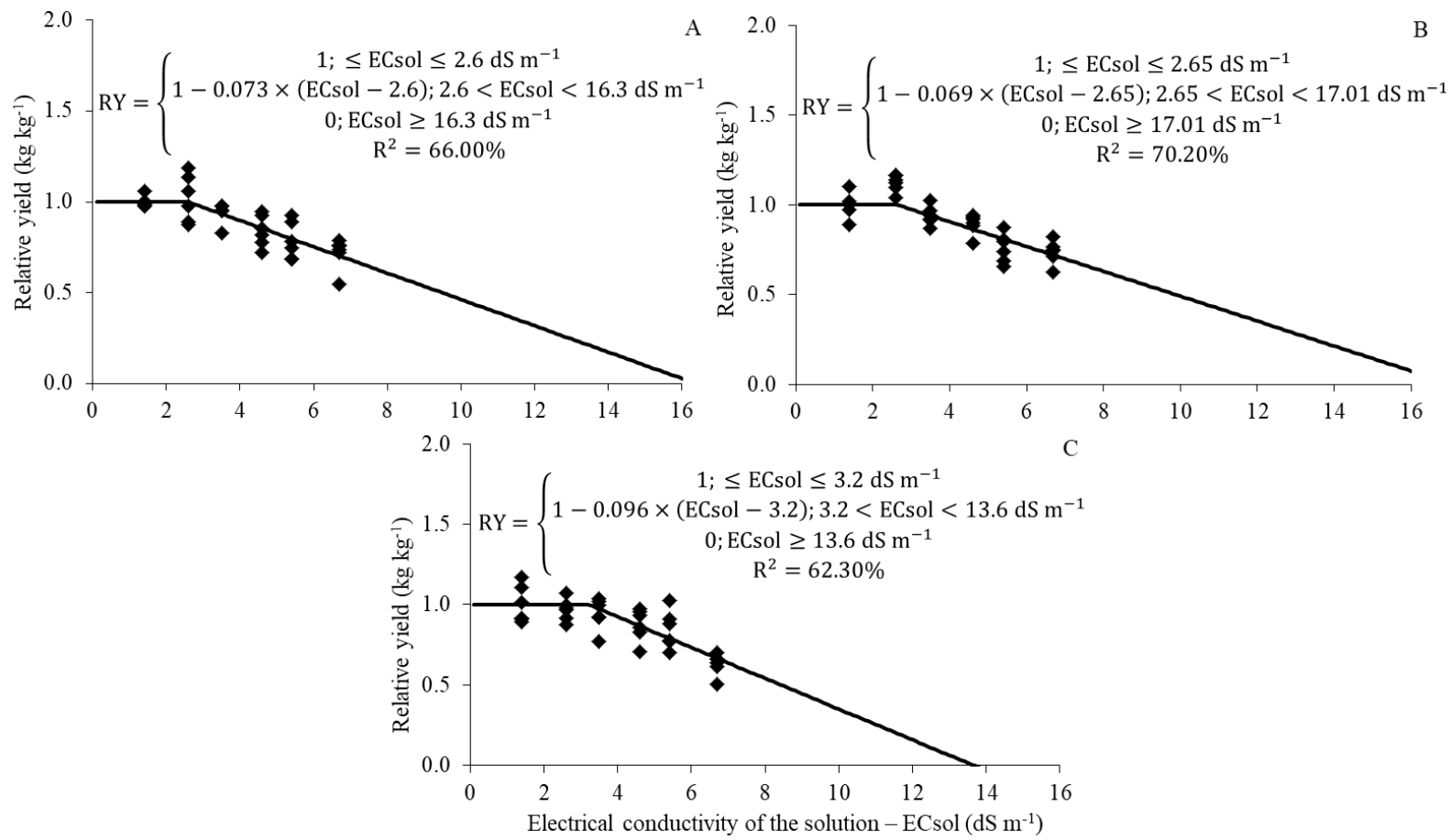

Figure 4. Relative yield (RY) of cauliflower cultivars 'Piracicaba de Verão' (A), 'Sabrina'(B) and 'SF1758'(C) as a function of mean time-weighted of electrical conductivity of the nutrient solution (ECsol) in a NFT hydroponic system.

\section{CONCLUSIONS}

The leaf area was the growth variable most affected by the increases in the electrical conductivity of the nutrient solution, and contributed the most to the decreases in shoot dry matter of cauliflower plants grown in the hydroponic system.

The inflorescence production data indicated that the cultivars 'Sabrina' and 'Piracicaba de Verão' are moderately sensitive to salt stress, which presented salinity thresholds of 2.65 and $2.60 \mathrm{dS} \mathrm{m}^{-1}$, respectively. The cultivar 'SF1758' was classified as moderately tolerant, presenting a salinity threshold of $3.20 \mathrm{dS} \mathrm{m}^{-1}$, and was the most promising cultivar to be grown in a hydroponic system under salt stress conditions.

\section{ACKNOWLEDGEMENTS}

To the Bahia State Research Support Foundation (FAPESB) for granting the Master's scholarship to the first author (order No. 2531/2018: grant term - No. BOL0738/2018) and for the financial support, to the Coordination for the Improvement of Higher Education Personnel
(CAPES), to the National Institute of Science and Technology in Salinity (INCTSal) and to the National Council for Scientific and Technological Development $(\mathrm{CNPq})$ for the financial support. We also thank the Post Graduate Program in Agricultural Engineering (PPGEA) of the Federal University of Recôncavo of Bahia for supporting the research project. Finally, we also thank the Feltrin ${ }^{\circledR}$ Seeds Company for donating of cauliflower cultivars tested in the study.

\section{REFERENCES}

ABDELGAWAD, $H$. et al. High salinity induces different oxidative stress and antioxidant responses in maize seedlings organs. Frontiers in Plant Science, 7: 276, 2016.

ALVARES, C. A. et al. Köppen's climate classification map for Brazil. Meteorologische Zeitschrift, 22: 711-728, 2013.

AUGUSTO, L. G. S. et al. O contexto global e nacional frente aos desafios do acesso adequado à água para consumo humano. Ciência \& Saúde 
Coletiva, 17: 1511-1522, 2012.

AYERS, R. S.; WESTCOT, D. W. Water quality for agriculture. Rome: Food and Agriculture Organization of the United Nations, 1985. 188 p. (FAO. Irrigation and Drainage Paper, 29).

BIONE, M. A. A. et al. Crescimento e produção de manjericão em sistema hidropônico NFT sob salinidade. Revista Brasileira de Engenharia Agrícola e Ambiental, 18: 1228-1234, 2014.

CRUZ, A. F. S. et al. Stress index, water potentials and leaf succulence in cauliflower cultivated hydroponically with brackish water. Revista Brasileira de Engenharia Agrícola e Ambiental, 22: 622-627, 2018.

De PASCALE, S.; MAGGIO, A.; BARBIERI, G. Soil salinization affects growth, yield and mineral composition of cauliflower and broccoli. European Journal of Agronomy, 23: 254-264, 2005.

DIAS, N. S. et al. Produção de melão rendilhado em sistema hidropônico com rejeito da dessalinização de água em solução nutritiva. Revista Brasileira de Engenharia Agrícola e Ambiental, 14: 755-761, 2010.

DING, X. et al. Electrical conductivity of nutrient solution influenced photosynthesis, quality, and antioxidant enzyme activity of pakchoi (Brassica campestris L. ssp. Chinensis) in a hydroponic system. Plos One, 13: e0202090, 2018.

FERREIRA, D. F. Sisvar: a computer statistical analysis system. Ciência e Agrotecnologia, 35: 1039-1042, 2011.

FREITAS, W. E. S. et al. Sulfur-induced salinity tolerance in lettuce is due to a better $\mathrm{P}$ and $\mathrm{K}$ uptake, lower $\mathrm{Na} / \mathrm{K}$ ratio and an efficient antioxidative defense system. Scientia Horticulturae, 257: 108764, 2019.

FURLANI, P. R. et al. Cultivo hidropônico de plantas. Campinas, SP: IAC, 1999. 52 p. (Boletim Técnico, 180).

GIUFFRIDA, F. et al. Effects of $\mathrm{NaCl}$ salinity on yield, quality and mineral composition of broccoli and cauliflower. Acta Horticulturae, 1005: 531536, 2013.

GIUFFRIDA, F. et al. Cultivation under salt stress conditions influences postharvest quality and glucosinolates content of fresh-cut cauliflower. Scientia Horticulturae, 236: 166-174, 2018.

GIUFFRIDA, F. et al. Effects of salt stress imposed during two growth phases on cauliflower production and quality. Journal of the Science of Food and Agriculture, 97: 1552-1560, 2017.

GOMES, J. W. S. et al. Crescimento e produção de tomate cereja em sistema hidropônico com rejeito de dessalinização. Revista Ciência Agronômica, 42: 850-856, 2011.

INSTITUTO NACIONAL DE METEOROLOGIA INMET. Dados históricos anuais. Disponível em: $<$ https://portal.inmet.gov.br/dadoshistoricos>. Acesso em: 19 set. 2019

JOUYBAN, Z. The effects of salt stress on plant growth. Technical Journal of Engineering and Applied Sciences, 2: 7-10, 2012.

LIRA, R. M. et al. Production, water consumption and nutrient content of Chinese cabbage grown hydroponically in brackish water. Revista Ciência Agronômica, 46: 497-505, 2015.

MAAS, E. V.; HOFFMAN, G. J. Crop salt tolerance -current assessment. Journal of the Irrigation and Drainage Division, 103: 115-134, 1977.

MAGGIO, A. et al. Physiological response of fieldgrown cabbage to salinity and drought stress. European Journal of Agronomy, 23: 57-67, 2005.

MARCOLINI, M. W.; CECÍLIO FILHO, A. B.; BARBOSA, J. C. Equações de regressão para a estimativa da área foliar de couve-folha. Científica, 33: 192-198, 2005.

MAY, A. et al. A cultura da couve-flor. Campinas, SP: IAC, 2007. 36 p. (Série Tecnologia APTA. Boletim Técnico, 200).

MODESTO, F. J. N. et al. Crescimento, produção e consumo hídrico do quiabeiro submetido à salinidade em condições hidropônicas. Irriga, 24: 86-97, 2019.

MUNNS, R. Comparative physiology of salt and water stress. Plant, Cell \& Environment, 25: 239250, 2002.

MUNNS, R; TESTER, M. Mechanisms of salinity tolerance. Annual Reviews of Plant Biology, 59: 651-681, 2008

NEUMANN, P. Salinity resistance and plant growth revisited. Plant, Cell \& Environment, 20: 11931198, 1997.

NOBRE, R. G. et al. Crescimento e floração do girassol sob estresse salino e adubação nitrogenada. Revista Ciência Agronômica, 41: 358-365, 2010. 
PROGRAMA HORTI \& FRUTI. Normas de identidade, padronização e classificação da couveflor (Brassica oleracea L. var. botrytis L.) para o programa brasileiro para a melhoria dos padrões comerciais e embalagens de hortigranjeiros. Disponível em: <http://www.hortibrasil.org.br/ classificacao/couveflor/arquivos/norma.htm>.

Acesso em: 13 out. 2019.

RODRIGUES, L. R. F. Técnicas de cultivo hidropônico e de controle ambiental no manejo de pragas, doenças e nutrição vegetal em ambiente protegido. Jaboticabal, SP: FUNEP, 2002. 762 p.

RAHNAMA, A. et al. Stomatal conductance as a screen for osmotic stress tolerance in durum wheat growing in saline soil. Functional Plant Biology, 37: 255-263, 2010.

SANOUBAR, R. et al. Salinity thresholds and genotypic variability of cabbage (Brassica oleracea L.) grown under saline stress. Journal of the Science of Food and Agriculture, 96: 319-330, 2016.

SCHIATTONE, M. I. et al. Water use and crop performance of two wild rocket genotypes under salinity conditions. Agricultural Water Management, 194: 214-221, 2017.

SOARES, H. R. et al. Salinity and flow rates of nutrient solution on cauliflower biometrics in NFT hydroponic system. Revista Brasileira de Engenharia Agrícola e Ambiental, 24: 258-265, 2020 .

SOARES, T. M. et al. Experimental structure for evaluation of saline water use in lettuce hydroponic production. Irriga, 14: 102-114, 2009.

SOARES, T. M. et al. Combinação de águas doce e salobra para produção de alface hidropônica. Revista Brasileira de Engenharia Agrícola e Ambiental, 14: 705-714, 2010.

TAVAKKOLI, E.; RENGASAMY, P.; MCDONALD, G. K. The response of barley to salinity stress differs between hydroponic and soil systems. Functional Plant Biology, 37: 621-633, 2010 .

WAN, S. et al. Effect of saline water on cucumber (Cucumis sativus L.) yield and water use under drip irrigation in North China. Agricultural Water Management, 98: 105-113, 2010. 